\title{
From 17th to 18th Party Congress: Implications for Intra-Party Democracy
}

\author{
CHEN GANG
}

\begin{abstract}
Growing intra-party pluralism and intensified factional rivalry have pressured the leadership of the Communist Party of China (CPC) to adjust the authoritarian official-selection system by resorting to an 'intra-Party democracy' mechanism based on informal polls among influential party officials and retirees. The progress, albeit slow and opaque since the 17th Party Congress in 2007, is increasingly seen as the CPC's only solution to intensified factional rivalry at various levels and the decline of legitimacy associated with the corrupt and inept officialdom. With backroom straw polls setting new norms for the CPC to settle factional infighting over power transfer at the 18th Party Congress, this intra-party democracy procedure has been gradually routinized at both the central and local levels to make the appointment process more consultative and to fend off democratic outcries from the public. In the past few years, cautious but substantial experiments with contested polls have been introduced by CPC's organizational departments to the monolithic political system, in which key party/government officials are facing increasingly competitive voting tests before they can be promoted to higher levels.
\end{abstract}

Keywords: China, election, intra-party democracy, leadership change, political reform

\section{Introduction}

The term 'intra-Party democracy,' which appeared in the Communist Party of China's (CPC) documents as early as the 8th Party Congress in 1956 and has been reiterated by all the Party Congresses since the end of the Cultural Revolution (Qian 2012), to a large extent has been political rhetoric aired by the CPC leadership with no substantive significance. However, the 17th Party Congress, on the eve of which Xi Jinping and Li Keqiang reportedly had been selected as heirs apparent from a backroom straw poll among party tycoons, demarcated the start of a new period when the CPC had to adjust its authoritarian official-selection system by relying more on informal polls and consultations inside the Party. ${ }^{1}$ 
$\mathrm{Hu}$ Jintao and Wen Jiabao, albeit having more political room to manoeuver in their second term following the 17th Party Congress, were stalled by a spate of unexpected disasters, events and strong vested interests from making substantial progress in pushing forward political reform. Nevertheless, to assume that intra-party democracy still remains a hollow rhetorical formulation risks overlooking dynamic and potentially far-reaching changes within the CPC (Li 2009). Among various adaptive measures the CPC has taken in response to the decay of organizational apparatus and a decline of legitimacy, the move towards intra-party democracy may be the most conspicuous approach for the top leadership to remain flexible and resilient by making the promotion process more meritocratic and consultative. Since 2007, as part of the CPC's reinstitutionalization process that succeeded in producing 'authoritarian resilience' (Nathan 2003: 6-17), intra-party democracy has been put into concrete action in a manageable way to encourage elite competition inside the CPC and alleviate public pressure for general democracy.

Leadership succession at the top level and the more regular mid-career official selection are vital organizational issues for the effectiveness and longevity of the Leninist one-party control of the country. Intraparty democracy, which is being gradually formalized, routinizes the competitive balloting system within the Party and moralizes the CPC's power monopoly in the face of an increasingly pluralistic society. It is essentially a mixture of political façade being built by the CPC to fend off democratic outcries as well as cautious but substantial experiments in introducing contested elections to the monolithic political system. This article examines major steps the CPC has been taking during the interval between the 17th and 18th Party Congress to promote intra-party democracy, to assess the merits and constraints of screening out eligible officials through contested but manageable polls within the Party.

\section{The 'Intra-Party Democracy' Story at the 17th Party Congress}

The CPC is the only party that organizes political life in China, and power succession is the agenda with the highest priority for every party leadership. Without transparent institutions for leadership change as in a democracy, the Chinese leadership has to find other means to cope with the succession issue. Succession has been affecting the country's political stability since the establishment of the People's Republic of China (PRC) in 1949. Mao Zedong ruled China for several decades, when bitter 
political struggles that resulted from power succession occurred and plunged the country into chaos, as in the case of his appointed successors Liu Shaoqi and Lin Biao (Rush 1974; Liu 1976). After returning to power, Deng Xiaoping, a victim of Mao's personal dictatorship, realized the importance of institutionalized power succession. However, power succession during the Deng era also did not go smoothly, as evidenced by the ousting of $\mathrm{Hu}$ Yaobang and Zhao Ziyang by irregular political means. Afterwards, both Jiang Zemin's paramount leadership and $\mathrm{Hu}$ Jintao's heir apparent status were confirmed, based on Deng's unchallengeable political authority. With the passing of the older generation of leaders, the issue of power succession becomes increasingly important. Since China's new leaders lack the personal and autocratic power that their old counterparts shared based on their revolutionary experience, they have to build up new power bases by discovering new rules and methods. Hu Jintao, like his predecessor Jiang Zemin, could not dictate his own successor, so he had to appeal to other means in handling power succession.

It was reported that prior to the 17th Party Congress in 2007, the CPC Central Organization Department held a tentative election among officials at the provincial/ministerial level and above, asking them to vote on candidates for Politburo Standing Committee members. Over 400 people, including members and alternate members of the 16th CPC Central Committee and leading officials of relevant departments, participated in picking proposed members of the Politburo from a list of almost 200 candidates. Hu Jintao presided over the event, on behalf of the CPC Central Committee, and set the conditions for the new Politburo members, with emphasis on political firmness, capacity and image among Party members and ordinary people. The candidates had to be 63 years or younger and in a position at least at the ministerial level, according to the rules. ${ }^{2} \mathrm{Xi}$ Jinping got the most votes, followed by Li Keqiang, He Guoqiang and Zhou Yongkang (Duowei 2007: 2). For the purpose of political stability, $\mathrm{Hu}$ and other leaders accepted the election results, implying that votes are important in deciding future leaders of the Party. Meng Jianzhu, who also obtained quite a number of votes during the process, was promoted from the obscure position of Jiangxi party secretary to the vice-premier-level State Councillor and authoritative Minister of Public Security. Hu was quoted as saying that the 'democratic recommendation' of the new Party leadership is of great importance for the $\mathrm{CPC},{ }^{3}$ which has over 70 million members and is managing a country with a population of 1.3 billion. 
While one still does not know what actually happened to the so-called 'democratic process of electing the party leadership', it is true that for the first time the participants of the Central Committee's plenary session could impact the selection of Politburo members. The authority thus regarded this event as a milestone in the history of the Party's efforts to develop internal democracy. Political struggles for power succession had troubled the CPC leadership since the birth of the CPC, and since now no single leader dictates the power succession, new institutions and methods, including ones with democratic elements, have to be instituted. As indicated in the title of the report, this is for the stability of the Party and the state. Therefore, despite its opaqueness and lack of supervision, the intra-party 'election' still helped to change the rules of the game on the succession issue and became an important step to push forward intra-party democracy. For years China has been attempting grass-roots elections and democracy at the village and township levels with caution, but the unexpected trial at the top level changed the bottom-up conception of China's political reforms.

Actually, the CPC is trying to combine the mechanisms of election and consultation with certain formal and informal criteria to be followed when selecting future top leaders. The former Chinese vicepresident Zeng Qinghong reportedly revealed the five criteria set by the Politburo Standing Committee in 2002 for choosing future leaders. ${ }^{4}$ According to Zeng, the Standing Committee had solicited the advice of former Politburo members on the candidate lists worked out on the basis of the five criteria. After 12 rounds of discussion and evaluation, the Standing Committee finally worked out a five-person list including Li Keqiang, Wang Yang, Ling Jihua, Xi Jinping and Li Yuanchao. Zeng not only mentioned the polls inside the Politburo, in which $\mathrm{Xi}$ and $\mathrm{Li}$ got almost the same number of votes, but also noted that the Politburo finally solicited opinions from retired leaders such as Wan Li, Jiang Zemin, Song Ping, Qiao Shi and Liu Huaqing, most of whom suggested Xi would be more suitable.

Such an intra-party 'democratic assessment' (minzhu pingyi) mechanism through voting and consultation has been expanding to a wider range. Before the annual session of the National People's Congress in March 2008, candidates for new state, parliamentary and cabinet leaders all went through such scrutiny starting in November 2007. The CPC Secretariat sent out candidate lists and questionnaires to local provincial leaders, soliciting their opinions on high-level personnel arrangements. Such a procedure has gradually been institutionalized and expanded to 
various provincial-level regions to select candidates for local leadership positions since the 17th Party Congress.

The political capital of Chinese paramount leaders since the founding of the PRC in 1949 has been diminishing with each generation. A farewell to strongman politics has pushed China's leadership structure forward in an increasingly power-sharing direction that facilitates intra-party consultations, bargaining and even secret polls behind closed doors. The weaker the top leader is, the more he will rely on 'collective decisionmaking' (jiti juece) when appointing successors and enacting national strategies. Certain informal rules and institutions based on balance of power among different factions and the restriction of top leaders' power have entered China's elite politics. This ensures that candidateship of future successors is not solely a reflection of the incumbent top leader's own will, but an outcome of compromises among different groups, and one step further, the result of polls in a limited range. This way of producing future leadership guarantees policy continuation and stability while forestalling individual dictatorship.

\section{More Polls at the Local Level}

When the CPC was reshuffling thousands of Party committee secretaries and members of the Party committees at various levels before the 18th Party Congress, three municipalities in the eastern part of Jiangsu Province made changes to the non-transparent selection process by introducing contested elections to select top Party leaders. As an experimental move towards intra-party democracy, Wuxi, Nantong and Suqian cities in Jiangsu Province for the first time in history nominated a total of 1,127 candidates for the three Party secretary positions. After going through two rounds of screening by two panels of provincial-rank cadres based in Jiangsu, the list was narrowed down to six candidates. Members of the Standing Committee of the Jiangsu Provincial Party Committee then balloted and the three with the highest votes became the Party secretaries of the three cities. ${ }^{5}$

The new selection mechanism, called 'open recommendations and balloting' (gongtuipiaojue), was supported by Li Yuanchao, then Jiangsuborn director of the powerful CPC Organization Department in charge of cadre promotion and demotion. Li was promoted to vice-president of China in 2013. Observers viewed the balloting within the Provincial Party Committee as a promising sign of introducing more competitive procedures into the selection of city-level officials. China started direct 
village elections in 1988; now almost every village in China-home to some 600 million farmers - is required to hold direct elections regularly for a new village committee vested with the power to decide important issues such as land and property rights. However, since village committees are formally excluded from China's five-level governmental apparatus (central, provincial, municipal, county and township), and more villagers are settling down in urban areas, such grass-roots elections can only play a limited role in China's democratization. Semi-competitive elections have moved to the township level, with increasing experimentation especially since 1998, in places like Lingshan in Sichuan Province, Caiji in Jiangsu Province ${ }^{6}$ and Dapeng in Guangdong Province. ${ }^{7}$ From late 2001 to early 2002, about 2,000 townships in Sichuan Province implemented semi-competitive elections (Lai 2004). ${ }^{8}$

Meanwhile, bribery and violence have degraded grass-roots elections of the Party's branches and the villagers' self-governing bodies. According to an investigation conducted by provincial prosecutors, the heads of more than half of the 18 villages or communities in Longquan township of Haikou City, Hainan Province, were elected after buying votes or feting voters. In some cases, local hooligans and gangsters intimidated villagers to vote for particular candidates. ${ }^{9}$

After years of experimentation, the Chinese authorities are still reluctant to promulgate semi-competitive elections for Party/government positions above the township level. ${ }^{10}$ Due to the slow progress in promoting elections, Wang Yukai, a professor from the China National School of Administration, has urged the Party-state to select county leaders through intra-party balloting. ${ }^{11}$ To bring political reforms in line with economic reform in China, the Party is trying to rely more on the contested intra-party balloting system than the opaque one-candidateone-position appointment process to select high-rank cadres. However, the Party has not deviated much from its traditional way of selecting cadres. Selection is still largely based on meritocracy and loyalty rather than democracy. Competitive elections are means and not an end to help the Party single out capable and loyal officials for important positions, and exclusive elections are just a part of the Party's complicated system of cadre selection based on meritocratic principles and political integrity. As a result, Jiangsu's experimentation with a more transparent and more competitive process to reshuffle local leadership did not yield any surprises. The Party's favourite candidates still emerged winners in the elections and the entire process is still controlled by the provincial Party committee. 
Mao Xiaoping from Wuxi, Ding Dawei from Nantong and Miao Ruilin from Suqian were all mayors in their respective cities and their challengers also held key positions in the provincial Party committee. Going from mayor to municipal Party secretary is the norm in China's politics. Meanwhile the comprehensive process used in Jiangsu Province is not mandatory and local authorities can opt not to follow it.

Nevertheless, Jiangsu's reform was clear evidence of the Party's will to promote openness and competition and to implement contested elections (cha'e xuanju) in cadre selection. The CPC has been making slow but continuous progress in expanding 'cha'e xuanju,' as members of the 18th CPC Central Committee were elected with a 9.3 per cent margin, higher than the 7.7 per cent at the 17th Party Congress. ${ }^{12}$

Besides Jiangsu, other places such as Beijing city and Zhejiang Province have also made similar changes to the selection process of department chiefs. Beijing, Zhejiang, Hunan, Jiangxi and Guangdong have opened up high-level civil vacancies to a broad range of qualified candidates who need to go through exams, interviews and balloting before they can be appointed to their respective positions.

\section{'Democratic Recommendation': CPC's System of Selecting Cadres}

The objective of cadre selection reform, an indispensable move to fulfil 'intra-party democracy,' is to make sure that professionally competent people are recruited and promoted, and that they remain loyal to the CPC's ideologies and political views (Brødsgaard 2001). All Party and government officials are managed by the Party according to detailed regulations relating to recruitment, appointment, transfer, reward, training, etc. (CPC Central Organization Department and the Ministry of Personnel 2008), which supplement the Civil Service Law. Concerning the management of cadres above the county/division level (xianchu $j i)$, the most important provisions are contained in the 'Regulation on Selection and Appointment of Party and Government Leading Cadres' (dangzheng lingdao ganbu xuanba renyong gongzuo tiaoli) issued in 2002 by the CPC Organization Department.

All these regulations emphasize that when selecting and appointing leading cadres in the Chinese civil service system, a number of basic principles including openness, equality, competition and the selection of the best must be adhered to. Although selection and appointment are based on meritocratic principles (ren ren wei xian), cadres should also 
have both political integrity and ability (de cai jian bei) and are ultimately managed by the Party (dang guan gan bu) (CPC Central Organization Department 2002: Article 2). Civil servants to be promoted to leading Party and government posts at section (village)-head level are required to have at least a college diploma (dazhuan) and have worked at the deputy post for more than two years (CPC Central Organization Department and the Ministry of Personnel 2008: Article 19). Candidates to be promoted to posts higher than the county (division) level must have held at least two posts at lower level organs; candidates who are promoted from a deputy post to a head post (zhengzhi) generally must have worked at the deputy post for more than two years (CPC Central Organization Department 2002: Article 7). Leading cadres at the bureau level (ju, si, ting) or above should have at least a bachelor's degree (daxue benke) (CPC Central Organization Department 2002: Article 7).

Candidates to be considered for selection and appointment to leading posts should be proposed through the so-called democratic recommendation process (minzhu tuijian) (CPC Central Organization Department 2002: Articles 10-19) conducted by the Party committee at the same level, or by a higher-level organization or personnel department. At the time of an official's change of term, various people and personnel are consulted, including Party committee members, leading members of government organs, leading members of the discipline inspection commissions and people's courts, and leading members of lower-level Party committees and governments. Members of democratic parties and representatives of groups without Party affiliation will also be consulted.

A candidate who has been nominated will have to undergo evaluation (kaocha) (CPC Central Organization Department 2002: Articles 20-28) based on elaborate procedures, which may include interviews with a number of leading officials in his or her own department. Evaluations are held throughout the official term. Leading members of Party committees and government departments are also evaluated in the middle of their term. Any promotion or dismissal arising from the evaluations must undergo a process of deliberation (yunniang) and be reported to the Party committee at the higher level.

The regulations require a two-thirds quorum of members of a given committee when appointment or dismissal of cadres is involved. The regulations include details concerning job transfer. Any leading member of a local Party committee or government who has served in the same post for ten years must be transferred to a new post. The Party has worked out a new plan for 'deepening the cadre management system' 
covering the 2010-2020 period (CPC Central Organization Department 2009). The plan further details and expands the provisions of the 2002 regulations, which are applicable to the entire cadre corps and not just leading cadres. The plan, with an emphasis on 'democratic recommendation', 'public opinion polls' and 'contested elections' (cha'e xuanju), is a reflection of the preoccupation of China's leadership with selecting qualified cadres. The focus of this theme goes back to October 2004, when former vice-president Zeng Qinghong published an important article in the People's Daily, in which he stressed the importance of strengthening the Party's governing capacity. Zeng discussed the 'painful lesson of the loss of power' by the communist parties in the former Soviet Union and Eastern Europe. ${ }^{13} \mathrm{He}$ attributed the collapse of the Soviet Communist Party to the rigidness and inflexibility of its governing system, which ultimately led to the Party's diminishing capacity to govern. To Zeng, establishing clear rules and regulations and ensuring constant cadre renewal were necessary to attract new talent.

\section{Growing Pluralism inside the CPC}

The transformation of the CPC has been very rapid. Since no opposition party is allowed, entering into the political process of the CPC is the most efficient way for social groups to express their interests. To a large extent, the 'three represents ${ }^{14}$ proposed by the CPC in the early 2000s typically reflected its realistic perception that the CPC has to represent different social interests (Zheng 2004: 253-281). Since the reform and opening up, the most obvious change in the Chinese society is the rise of the middle class ( $\mathrm{Li} 2010)$. The number of Chinese middle class, including private entrepreneurs, is not large, but they have already demonstrated very strong demand for political participation. This is why the ruling party has kept pace with the times by not only providing constitutional protection to non-state-owned sectors, including private enterprises, but also allowing and encouraging private entrepreneurs to join the ruling party.

Behind the 'three represents' are various social and economic interests. To represent different social interests requires the CPC to be open to including different social interests into one political process. The change in the nature of party members is an indicator. In the Maoist era, workers, peasants and the People's Liberty Army (PLA) constituted the majority of CPC membership; since the reform and opening up, intellectuals, professionals and the emerging middle class have made 
up an increasing proportion of the party (Zheng 2010; Gore 2011). If the West practices 'external pluralism', the Chinese party system tends to be characterized by 'internal pluralism'. Different interests are 'internalized' first, that is, included in the existing system, to compete for and coordinate their interests within. After the successful incorporation of private entrepreneurs into the party and the political process, the $\mathrm{CPC}$ has begun to put emphasis on 'social management' to expand its ruling foundation by absorbing more social forces, which have gained significantly in growth and development in the past decade. As the social base of the CPC enlarges, the demand for intra-party democracy has also increased. This is why the ruling party has been emphasizing the importance of intra-party democracy and searching for manifold inner-party democracy in recent years.

China has refused to follow the path of Western democracy and has developed a unique system of power succession. This should be attributed to the late Deng Xiaoping after he returned to power in the late 1970s. Deng was successful in establishing two related systems, one is the exit system for aged leaders, i.e., the retirement system; the other is the recruitment system to recruit talent from all levels of society. This system of power succession has been highly institutionalized from the grass roots to the highest leadership (Zheng 2005: 15-36). Compared with many other authoritarian regimes, the CPC has regularized the age limit for officials at all levels, which facilitates elite succession and avoids the personal dictatorship from Mao's time. Now, in general, leaders including the general secretary of the CPC, the president of the state, premier and other important positions are allowed to serve at most two terms in office, i.e., ten years. The term limit is an effective institutional constraint on personal dictatorship. That is to say, although China does not have a Western form of democracy, it has found another way of forestalling personal dictatorship. By contrast, in some developing countries, personal dictatorship is commonplace in both the monarchical countries and those with a modern party system. When a person or a family has ruled a country for several decades, the system is prone to malpractice and corruption, which are intolerable for the society.

The CPC's re-institutionalization effort since the late-1990s, ${ }^{15}$ which included civil service reform (Brødsgaard and Chen 2014: 77-99), rebuilding of party cells and core groups (dangzu), more meritocratic promotions based on prudent personnel assessments (kaohe) and frequent anti-corruption campaigns, ${ }^{16}$ has managed to refresh inner-party politics at a 
relatively faster pace, and thus reversed the trend of atrophy by making the Party more dynamic and efficient. With rigid enforcement of the age limit and disciplinary inspections, there are thousands of officials leaving their positions every year, with the same number of officials assuming these positions.

Besides the role in institutionalizing the succession process and preventing disruptive inner-party strife, intra-party democracy has another important task, namely, to remain sensitive and responsive to social demands. Even in Western multiparty democracies, the behaviour of individuals and firms in stable societies leads to the formation of dense networks of collusive, cartelistic, lobbying organizations that make economies less efficient and dynamic and polities less governable. The CPC that has been ruling China for more than six decades is now facing similar challenges from all kinds of vested interests within the system. The unprecedented anti-corruption campaign launched by Xi Jinping, who himself was selected out of the intra-party democracy process, has shown that further reform is possible in energy, banking and media sectors where some entrenched vested interests have been eradicated in the anti-graft purge.

\section{Elections Lacking in China's Elite Selection}

China traditionally adopted the examination and recommendation system rather than competitive elections when selecting its officials. During the Han Dynasty (206 BC-220 AD), most appointments in the imperial bureaucracy were based on recommendations by prominent aristocrats and local officials. Recommended individuals were mostly from aristocratic families. When the Sui Dynasty (581-618 AD) established the imperial examination system in $605 \mathrm{AD}$, ancient China began to select most of its administrative officials from among civilians through institutionalized imperial examinations. However, even during that period, bureaucratic appointments did not fully rely on examination results but sometimes upon the recommendation of powerful people.

This cultural heritage still has significant impact upon today's Chinese politics, with the Party-state largely reliant on the civil service examinations for recruiting grass-roots cadres and recommendations from political elites of the Party committees at various levels for the promotion of officials. In most cases, the Party secretary or the administrative chief (yibashou, or chief official of the organization) in the Party committee has the arbitrary power to make promotion decisions. 
The non-transparent process of promoting officials recommended by the yibashou has caused rampant, corrupt practices such as the selling and buying of government posts or bribing for higher positions. In one of China's largest 'selling official posts' scandals, Ma De, former Party secretary of Suihua City in Heilongjiang Province, was charged with taking bribes amounting to more than 6 million yuan (US\$726,000) between 1992 and 2001. Most of the bribes were offered by ambitious county heads and leading officials of government departments under Ma's jurisdiction. More than 260 government officials were alleged to be involved in Ma's case, including Tian Fengshan, former minister of land and resources, and Han Guizhi, former chairwoman of the Heilongiiang Provincial Committee of the Chinese People's Political Consultative Conference (CPPCC). ${ }^{17}$

The recent increase in corruption cases involving ministerial/provincial-level officials has raised concern over the selection criteria and procedures for senior officials (Chen and Zhu 2009: 1-3). The scandals involving selling official posts have undermined the Party's promotion principle that cadres should have both political integrity and ability (de cai jian bei). This has also put the Party's reputation and legitimacy at stake.

The Party issued its first interim regulation on the selection and appointment of officials in 1995, which included detailed procedures regarding nomination, screening, transferring, discipline and monitoring; the regulation was revised into a formal statute in 2002. Although the institutionalization of elite management has introduced a number of mechanisms to curb arbitrary personnel decisions while enhancing the institutional dominance of the Party (Bo 2004: 99), the lack of competitive elections throughout the system has made the official selection process less fair and transparent.

China has institutionalized direct village elections in most parts of the country, but since village committees are formally excluded from China's five-level governmental apparatus, such grass-roots elections can only play a limited role in promoting democratization and officials' accountability.

Recent reports have revealed that the Party is encouraging polling within local Party committees to select county/district-level Party secretaries. In June 2011, seven candidates from different government departments competed for the Party secretary position of Yangxi County, Guangdong Province, by delivering speeches in front of over 100 voters from the upper-level Party Committee of the Yangjiang City. In 2008, 
four counties and districts under Guiyang City, Guizhou Province, made their top positions of Party secretary open to qualified Party-member competitors, who had to go through contested polling within the municipal Party committee in Guiyang. ${ }^{18}$

\section{The 18th Party Congress: A New Norm?}

Although the Party itself is becoming more pluralistic, propelling its leadership structure towards an increasingly power-sharing direction that facilitates intra-party consultations, bargaining and closed-door polling, institutionalization of intra-party democracy is still weak and full of uncertainties. Constraints on institutionalization became evident when the CPC elite politics was moving from internal balloting before the 17th Party Congress to backroom dealing among factional representatives on the eve of the 18th Party Congress. There was little doubt that $\mathrm{Xi}$ would succeed $\mathrm{Hu}$ as party chief in 2012, but Hu's handover of both party and military reins to $\mathrm{Xi}$ at the same time still surprised many as a new norm for future power transitions. The mandatory retirement system, an institutional premise for intra-party democracy first advocated by Deng Xiaoping in the 1980s, was strictly followed at the Politburo level during the 17th and 18th Party Congress, while Hu's complete retirement from party and military posts was a step further along the path. Unlike the semi-retirement of his predecessors, Jiang and the late Deng, both of whom had kept the top military post for a couple of years after leaving the Politburo, Hu's complete exit ostensibly institutionalized a smoother power transition and made $\mathrm{Xi}$ a more formidable leader upon the start of his tenure.

Since behind-the-scenes jockeying for power and horse-trading had been extremely intense in the run-up to the long-planned power transition at the 18th Party Congress, the top leadership failed to select new members of the Politburo and its Standing Committee (PSC) through a large-scale intra-party poll as it did five years ago. China was plagued by political scandals and rumours since the Chongqing police chief, Wang Lijun, fled to the US Consulate in Chengdu in February 2012, foreboding high-flyer Bo Xilai's expulsion. Later, Ling Jihua, a close confidante of $\mathrm{Hu}$ Jintao, lost his key position as chief of the CPC General Office due to his son's death in a mysterious Ferrari car accident, dealing a blow to $\mathrm{Hu}$, who was seeking to fill important positions with his protégés before his retirement. On the eve of the 18th Party Congress, the new leadership line-up was said to be decided by backroom straw polls among 
influential party retirees and outgoing Politburo members (Reuters 2012; Li 2012: 133-135), which may set new norms for the CPC to settle factional infighting over power transfers based on such informal polls. Party elders prioritized seniority when handpicking the five newcomers in the Politburo Standing Committee. All the newcomers will be older than 68 years in 2017 and will thus be replaced at the next party congress. Of the five, Zhang Dejiang, Yu Zhengsheng, Wang Qishan and Zhang Gaoli used to be formidable gross domestic product (GDP) promoters in coastal provinces while Liu Yunshan played hardball when he was director of the Central Propaganda Department. Of the five, all but one are considered protégés of retired leader Jiang Zemin. ${ }^{19}$ Once-hopeful Li Yuanchao and Wang Yang failed to grab a seat in the PSC, the size of which was scaled down from nine to seven to enable power concentration at the top.

Party elders, once formidable political players in deciding CPC's top leaders and policy directions in the 1980s, are continuing to play a vital role in influencing the outcome of high-level polls. Despite Hu's complete retirement, China's elite politics today is still affected by gerontocracy in which retired leaders who have no formal positions can continue to exercise substantial political influence through various informal ways behind the scenes. ${ }^{20}$ This was particularly true of Jiang Zemin who remained politically active on the eve of the 18th Party Congress that witnessed his protégés predominating over the Politburo and the PSC. The landslide victory won by the Jiang camp in the new PSC, however, does not necessarily mean that 'the winner takes all' in Chinese elite politics ( $\mathrm{Li}$ 2013). In his first year of office, Xi surprisingly embarked on probes into retired Zhou Yongkang and Xu Caihou, Jiang's key protégés, breaking the immunity of PSC members and Central Military Commission vice-presidents from corruption charges and changing the balance of power in a way that favours Hu's camp. Meanwhile, Hu's protégés are still well represented in other important leadership bodies such as the State Council, the CPC Secretariat and the Supreme People's Court (Li 2013).

On the institutionalization of cadre selection, the Party's long-term goal is still meritocracy rather than democracy. The rampant bribery and violence that have characterized grass-roots elections of the Party's branches and the villagers' self-governing bodies have reminded the Party of the innate flaws pertaining to popular elections. There have been greater dynamics for intra-party democracy after the passing of the strongman age. However, if intra-party competition is inevitable, 
formal rules and norms that can regulate competition will be crucial. To eliminate the possibility of hidden rules, competition rules will have to be explicit, fair and transparent. While intra-party democracy has been practiced, there are hardly any formal rules and norms at the moment. When hidden rules dominate political competition, democracy will be jeopardized. If democracy is jeopardized, intra-party competition will not only destroy the unity of the party but also weaken the overall ability of the ruling party, thus increasing the risk for political instability.

\section{Will Xi Be the Game-changer?}

President Xi Jinping emerged from the CPC's Third Plenum in November 2013 as the supreme authority, overseeing not only domestic security and diplomatic issues, but also economic affairs. His omnipotent power over socio-economic policies, the military, domestic security issues, propaganda and foreign affairs through the establishment of the National Security Council and the Central Leading Group on Comprehensively Deepening Reforms has challenged the Party's mechanism of collective leadership and intra-party democracy. $\mathrm{Xi}$ is no longer the first-among-equals in the Politburo Standing Committee. His assertiveness and power consolidation have altered the trajectory of top Chinese leaders who have witnessed diminishing political authority with each generation change. Xi brought back strongman politics, thus undermining the party's collective leadership mechanism where the power of a paramount leader is not absolute and is constrained by other Politburo Standing Committee members.

$\mathrm{Xi}^{\prime}$ 's charisma has impaired the lingering political influence of retired party elders such as Jiang Zemin, Hu Jintao and Li Peng, in crucial policy and personnel decisions. A political conservative, $\mathrm{Xi}$ has shown little interest in democratizing the country, or in promoting intra-party democracy that will impair his ability to dictate future successors. At the cost of freedom of speech and intra-party power sharing, Xi's authoritarian style is a precondition for bold economic reforms that run counter to vested interests, but may not be positive for the evolution of intra-party democracy. In this respect, the development of intra-party democracy still faces great uncertainty under $\mathrm{Xi}^{\prime}$ 's tenure, but given the magnitude of China's multilayer bureaucratic system and economic scale, as well as the unstoppable growth of inner-Party pluralism, the top leadership still has to resort to established procedures based on closed-door consultation and contested polling when reshuffling of- 
ficials in massive numbers. ${ }^{21}$ Even on the issue of next-round power succession, which will emerge at the 19th Party Congress, Xi will lack absolute power in hand-picking all the next-generation candidates to the elite Politburo Standing Committee. He may have the final say in deciding the heir apparent that will replace him in 2022, but on other key positions in the Politburo Standing Committee, he still has to defer to backroom horse-trading, and on some occasions, informal polls among party tycoons. Even with his 'red nobility' parentage that endows him with self-confidence and the mandate for handling thorny succession issues, $\mathrm{Xi}$ is expected to respect the existing formal and informal politics from which he himself has been selected as the top CPC leader. In another words, notwithstanding the seemingly unfettered power Xi has been enjoying compared to his predecessor $\mathrm{Hu}$ Jintao, Xi's capacity to select future leaders will still be constrained by the embedded formal and informal Party institutions that prevent overwhelming domination of one faction, encourage factional accommodation and thus reduce destructive power struggles.

\section{Conclusion}

Growing intra-party pluralism, intensified factional rivalry at various levels and the decline of legitimacy associated with the corrupt and inept officiald om have pressured the CPC leadership to adjust the authoritarian official-selection system by resorting to the 'intra-party democracy' mechanism based on informal polls among influential Party officials and retirees. The progress, albeit slow and opaque since the 17th Party Congress in 2007, is increasingly being institutionalized as the CPC's organizational approach to remain its 'authoritarian resilience' (Nathan 2003: 6-17; Wang and Tan 2013: 199-219). With backroom straw polls setting new norms for the CPC to settle factional infighting over power transfer at the 18th Party Congress, such 'intra-Party democracy' procedures have been gradually routinized at both the central and local levels to make the appointment process more consultative and to fend off democratic outcries from the public. The weaker the incumbent leader, the more likely he/she is to rely on 'collective decision-making' (jiti juece) when appointing a successor. In the past few years, cautious but substantial experiments of contested polls have been introduced by CPC's organizational departments to the monolithic political system, in which key party/government officials are facing increasingly competitive voting tests before they can be promoted to higher levels. 
The development of intra-party democracy still faces uncertainty given Xi's consolidated authority after the CPC's Third Plenum in November 2013, but Xi's power is not absolute and is still constrained by embedded formal and informal party institutions that prevent overwhelming domination of one faction, encourage factional accommodation and thus reduce destructive power struggles. He may be more powerful than his two predecessors in deciding his heir apparent, but on other key positions in the Politburo Standing Committee, he still has to seek consensus with other party elders, and on some occasions, they will have to resort to informal polls. On the selection of key officials at various levels below the Politburo, the top leadership, considering the magnitude of China's multi-layer bureaucratic system and economic scale, as well as more conspicuous inner-Party pluralism and factional politics, still needs to rely on closed-door consultation and contested polling.

Certain informal rules based on balance of power among different factions and restriction of incumbent leaders' power have emerged in China's elite politics, which restricts the top leader's power in handpicking his protégé as the future successor. Instead, the heir apparent will continue to be an outcome of compromises among different groups, or even one step further, the result of polls in a limited sense. Nevertheless, since no explicit rules have been established with regard to the opaque selection process, a polling mechanism is very fragile and prone to political manipulation, facing the risk of triggering disruptive political strife at the top. On some occasions, this way of producing future leadership guarantees policy continuation and stability while forestalling individual dictatorship and corruption, but without the full-fledged development of intra-party democracy institutions, the CPC will inevitably encounter great uncertainty and risks in dealing with power succession, a source of inordinate concern and outbursts of concentrated strife in its history. The opaque process by which the $\mathrm{CPC}$ decides its future leadership prevents the democratization procedure from being duplicated in other political realms. There is also no institutional guarantee that extensive interest of different social groups will be co-opted by future leadership, since lobbying activities could not work well in such a non-transparent process that lacks clear policy debates among potential candidates.

Chen Gang is a Research Fellow at the East Asian Institute, National University of Singapore.Email:eaicg@nus.edu.sg 


\section{NOTES}

1 Cheng Li (Brookings Institution, USA), who has done pioneering research on this topic, discussed the dichotomous views over the implications of China's 'intra-Party democracy' (Li 2009, 2010, 2012, 2013). Other research on a similar topic includes Lin (2004: 255-275); Thornton (2008: 2-22); Zheng and Chen (2009: 1-30).

2 Liu Siyang, Sun Chengbin, and Liu Gang, 2007, 'For the Prosperity and Stability of the Party and State: On the Spot Record of the Birth of the New Party Leadership' (Weile dang he guojia xingwang fada changzhi jiuan - dang de xin yijie zhongyang lingdao jigou chansheng jishi)', Xinhua News, 23 October.

3 Xinhua News, 23 October 2007

4 The five criteria are: 1) the age of the candidates range from 45 to 55 years old; 2 ) the candidates and their family members should be incorruptible; 3 ) the candidates have undergone tests in their political careers and found to have firmly adhered to the policies formulated by the 15th and 16th Party Congress; 4 ) the candidates have aspirations for the country's future; 5) the candidates can be accepted within and outside the CPC. See Dong Xiang (2008: 6-7).

5 People's Daily, 2011, 'Jiangsu for the first time selected three municipal party secretaries through open recommendations and balloting' (Jiangsu shouci gongtuipiaojue chansheng sanming shiweishuji), 19 April. Available at: http://renshi.people.com. cn/GB/14422048.html (accessed 2 January 2014).

6 China Daily, 2004, 'Direct Elections Move to Township Level', 18 May. Available at: http://www.chinadaily.com.cn/english/doc/2004-05/18/content_331594.htm (accessed 12 December 2013).

7 In an early model for further experiments on direct township election, all registered voters in Dapeng Town in Shenzhen, Guangdong Province, were allowed to participate in a form of sea election (haixuan, where any adult in the constituency can be a candidate in the election) to nominate candidates for town magistrate in 1999. Voters representing about one-fifth of the town's population and selected by the election organizing committee from among local officials, Party members, village committee members, villager-small-group chiefs, town resident committee members, and representatives of enterprises and unions, then voted for one among the five qualified candidates who received more than 100 votes on the first ballot, in what was called an 'opinion poll'. The winning candidate's name was then submitted to the township people's congress for a confirming vote. See Horsley (2001).

8 The term 'semi-competitive elections' is used because these elections are far from being free and competitive elections as one sees in many countries.

9 China Daily, 2010, 'Bribery being Bred in Grassroot Elections', 22 July. Available at: http://www.chinadaily.com.cn/china/2010-07/22/content_11033296.htm (accessed 13 December 2013).

10 There have been occasional reports recently about intra-party elections for countylevel party secretaries. See, for example, Xinhua News, 2011, 'CCP Tries to Push Political Elites onto Election Stage' (zhonggong changshi tuidong zhizheng zhiguo guganliliang zoushang jingxuan wutai), 12 June.

11 People's Daily 2010. 'Wang Yukai urges direct election of county leaders' (wangyukai: tuijin xianjizhixuan), 19 December. Available at: http://theory.people.com. cn/GB/11721480.html (accessed 14 December 2013).

12 Xinhua News, 2012, '18th CPC Central Committee elected with a 9.3\% margin' (shibajie zhongyang weiyuanhui weiyuan xuanju cha'e bili wei 9.3\%), 14 November.

13 People's Daily, 2004, 'Zeng Qinghong: A pivotal document on enhancement of CCP's ruling capacity' (zeng qinghong: jiaqiang dangde zhizhengnengli jianshe de ganglingxing wenxian), 8 October, pp. 2-3. 
14 In 2000, Jiang Zemin raised a new concept of san ge dai biao (literally 'three represents'). According to this concept, the CPC represents the most advanced production mode, the most advanced culture, and the interests of the majority of the people.

15 This is the main argument in Shambaugh (2008), McGregor (2010), and Brødsgaard and Zheng (2006).

16 Since the early 1990s, Chinese leaders have tended to embark on anti-corruption campaigns in their first year of office to consolidate power and court the public. An unprecedented number of officials at the vice-ministerial level and above have been investigated or detained under corruption charges after $\mathrm{Xi}$ Jinping came to power in 2012. Between November 2012 and June 2014, 30 incumbent senior officials have been investigated by CPC's disciplinary inspection departments. In comparison, the average number of officials at the vice-ministerial level and above investigated in Hu Jintao's second term (2008-2012) only reached six per annum.

17 China Daily, 2005, 'Official on trial for selling high-level jobs', 22 March. Available at: http://www.chinadaily.com.cn/english/doc/2005-03/22/content_427223.htm (accessed 11 November 2013).

18 Xinhua News, 2011, 'CCP Tries to Push Political Elites onto Election Stage' (zhonggong changshi tuidong zhizheng zhiguo guganliliang zoushang jingxuan wutai), 12 June.

19 Liu Yunshan, the Party's propaganda chief, has working experience in the Youth League and is often regarded as the only 'Hu-ist' among the five newcomers. See The Economist, 2012, 'Changing guard: China shuffles its leadership, putting a princeling in command,' 17 November. However, he is also believed to have very close ties with Jiang Zemin. See Li (2013).

20 Under Deng Xiaoping, the CPC established the Central Advisory Commission in 1982, which provided elderly Party leaders such as Chen Yun and Li Xiannian with a formal channel to influence decision making of the Politburo Standing Committee. This institution was one of the major sources behind the power struggles that led to the fall of both Hu Yaobang and Zhao Ziyang in the 1980s. Fortunately, Deng disassembled this organization when he formally retired from politics. However, Deng and his senior colleagues continued to influence politics and policies through informal channels after that.

21 There are diverging views as to whether the Chinese political system has become more dynamic and responsive to external changes. Literature with pessimistic views includes Pei (2006), Shirk (2007) and Waldron (2002: 171-179).

\section{REFERENCES}

Bo, Zhiyue 2004. 'The Institutionalization of Elite Management in China'. In Holding China Together - Diversity and National Integration in the Post-Deng Era, edited by Barry J. Naughton and Dali Yang, pp. 70-100. New York: Cambridge University Press.

Brødsgaard, Kjeld Erik 2001. 'China's Cadres: Professional Revolutionaries or State Bureaucrats? (I)'. Singapore: EAI Background Brief, no. 94.

Brødsgaard, Kjeld Erik, and Chen Gang 2014. 'Public Sector Reform in China: Who is Losing Out?' In Globalization and Public Sector Reform in China, edited by Kjeld Erik Brødsgaard, pp. 77-99. Abingdon: Routledge.

Brødsgaard, Kjeld Erik, and Zheng Yongnian (eds) 2006. The Chinese Communist Party in Reform. London: Routledge.

Chen, Gang, and Zhu, Jinjing 2009. China's Recent Clampdown on High-Stakes Corruption. Singapore: EAI Background Brief, no. 490.

CPC Central Organization Department 2002. 'Regulation on Selection and Appoint- 
ment of Party and Government Leading Cadres' (Dangzheng lingdao ganbu xuanba renyong gongzuotiaoli). Beijing: CPC.

CPC Central Organization Department 2009. 'The Plan for Deepening the Cadre Management System During the 2010-2020 Period' (2010-2020 nian shenhua ganbu renshi zhidu gaige guihua gangyao'). Beijing: CPC.

CPC Central Organization Department and the Ministry of Personnel 2008. 'Regulation on the Appointment, Dismissal, Promotion, and Demotion of Civil Servants (Trial)' (Gongwuyuan zhiwu renmian yu zhiwu shengjiang guiding (shixing)). Beijing: CPC.

Dongxiang, 2008. 'The Inside Story about How Xi Jinping and Li Keqiang Became Heirapparent', Dongxiang magazine, no. 275: 6-7.

Duowei 2007. 'The Election Process of New Members in the Standing Committee', Duowei Yuekan, no. 33: 2.

Gore, Lance L.P. 2011. The Chinese Communist Party and China's Capitalist Revolution: The Political Impact of Market. London: Routledge.

Horsley, Jamie P. 2001. 'Village Elections: Training Ground for Democratization'. The China Business Review March-April.

Lai, Hairong 2004. 'Semi-Competitive Elections at Township Level in Sichuan Province'. China Perspectives, no. 51.

Li, Cheng 2009. 'Intra-Party Democracy in China: Should We Take It Seriously?' China Leadership Monitor, no. 30.

Li, Cheng (ed) 2010. China's Emerging Middle Class: Beyond Economic Transformation. Washington, DC: Brookings Institution Press.

Li, Cheng 2012. 'The Battle for China's Top Nine Leadership Posts'. The Washington Quarterly 35 (1): 131-145.

Li, Cheng 2013. 'A Biographical and Factional Analysis of the Post-2012 Politburo'. China Leadership Monitor, no. 41.

Lin, Gang 2004. 'Leadership Transition, Intra-Party Democracy, and Institutional Building in China'. Asian Survey 44 (2): 255-275.

Liu, Alan P. L. 1976. Political Culture and Group Conflict in Communist China. Oxford: Clio Books.

McGregor, Richard 2010. The Party: The Secret World of China's Communist Rulers. New York: Harper.

Nathan, Andrew 2003. 'China's Resilient Authoritarianism'. Journal of Democracy 14 (1): 6-17.

Pei, Minxin 2006. China's Trapped Transition: The Limits of Developmental Autocracy. Cambridge: Harvard University Press.

Qian, Gang 2012. 'Intra-party Democracy: Breakthrough of the Reform?' (dangnei minzhu, gaige de qierudian?). The New York Times Online (in Chinese), 24 September. Available at: http://cn.nytimes.com/, http://cn.nytimes.com/article/china/2012/09/24/ cc24qiangang6 (accessed 1 January 2014).

Reuters 2012. 'China's Backroom Power Brokers Block Reform Candidates,' 21 November.

Rush, M. 1974. How Communist States Change Their Leaders. Ithaca, NY: Cornell University Press.

Shambaugh, David 2008. China's Communist Party: Atrophy and Adaptation. Berkeley: University of California Press.

Shirk, Susan 2007. China: Fragile Superpower. New York: Oxford University Press.

Thornton, John L. 2008. 'Long Time Coming: The Prospects for Democracy in China'. Foreign Affairs 87 (1): 2-22.

Waldron, Arthur 2002. 'Cracks in the Middle Kingdom'. Journal of Democracy 13 (2): 171-179. 
Wang, Zhengxu, and Ern Ser Tan 2013. 'The Conundrum of Authoritarian Resiliency: Hybrid and Nondemocratic Regimes in East Asia'. Taiwan Journal of Democracy 9 (1): 199-219.

Zheng, Yongnian 2004. 'Technocratic Leadership, Private Entrepreneurship and Party Transformation'. In Will China Become Democratic? Elite, Class and Regime Transition, edited by Zheng Yongnian, pp. 253-281. Singapore: Eastern Universities Press.

Zheng, Yongnian 2005. 'The 16th National Congress of the Chinese Communist Party: Institutionalization of Succession Politics'. In Leadership in a Changing China, edited by Weixin Chen and Yang Zhong, pp. 15-36. New York: Palgrave.

Zheng, Yongnian 2010. The Chinese Communist Party as Organizational Emperor: Culture, Reproduction and Transformation. New York: Routledge.

Zheng, Yongnian, and Gang Chen 2009. 'Xi Jinping's Rise and Political Implications'. China: An International Journal 7 (1): 1-30. 